\title{
Symposium on Education and Politics in a Global Age "A Different Kind of Politics"
}

\begin{abstract}
Harry C. Boyte*
In the age of what Gert Biesta calls subjectification, "the uniqueness of each individual human being," the promise of citizens-as-subjects is to break with the ideal of the "good citizen" whose identity is inscribed by state and market. Making such a break involves "exposure to the experiment of democracy," in Biesta's view. This essay argues that the promise is real but the danger is that subjectification becomes "identity politics" which erode the responsibility of citizens for society as a whole and generate bitter clashes as identities are manipulated by elites using social media and other technologies. "What is democracy?" is the question that marks the difference between subjects as co-creators and subjugation. To overcome the dangers and realize the possibilities of the age of the subject requires shifting paradigms from state-centered democracy to citizen-centered democracy. Citizen-centered democracy rests on conceptions of citizens as co-creators who undertake the collective, self-organized work of building society (which is a concept of the citizen which predates the modern state); and politics as pluralist, negotiation across differences. State-centered theories of democracy and associated ideas of the citizen and politics form the dominant paradigm today. Despite problems in Japanese political education such as passive instructional pedagogies, this essay argues that there are powerful resources in Japan's civic life and cultural history to push back against the dominant view and lay foundations for a paradigm of democracy as society. There is also current evidence of a shift from civic attachment to insular communities, bonding social capital, to what many theorists call "bridging social capital," which I argue is better described as pluralist citizen politics. The essay describes the experiment in democratic pedagogies and conceptual innovation of a new paradigm at Tokai University. It calls for international collaboration on this paradigm of citizen-centered democracy.
\end{abstract}

Keywords: civic agency; democratic society; citizen as cocreator; citizen politics; public work.

\footnotetext{
* Co-director, Public Work Academy

Senior Scholar in Public Work Philosophy, Augsburg University

e-mail: boyte@augsburg.edu
} 


\section{Introduction}

Professor Shigeo Kodama has argued that in Japan "the current problem of political education is how to make it be more critical and active for students" This is a global challenge. We live in the age of what Gert Biesta calls subjectification, "the uniqueness of each individual human being." 2 The promise of citizens as subjects is to break with the ideal of the "good citizen" whose identity is inscribed by state and market. "Learning here ...has to do with an 'exposure' to and engagement with the experiment of democracy," Biesta argues. "It is this very engagement that is subjectifying.",

The danger is that subjectification becomes "identity politics," neglecting the tasks and challenges of the society as a whole and generating bitter clashes as identities are manipulated by elites using social media and other technologies. Politics can become increasingly "who gets what?", mediated by the state to produce a Hobbesian war.

"What is democracy?" is the question that marks the difference between subjects as co-creators and subjugation. My argument today is this:

To overcome the dangers and realize the possibilities of the age of the subject requires shifting paradigms from state-centered democracy to citizen-centered democracy.

State-centered theories of democracy and associated ideas of citizenship are the dominant paradigm today. They shape the views even of many of those who take up the problems of exclusion. As the Swedish theorist Jonna Pettersson observes, "The fields of critical human rights theory and cosmopolitan and multicultural citizenship theory [reproduce] the criteria for political subjectification [as] inclusion in the [formal political] community, leaving the political subject without any emancipatory power of its own"4

Despite the problems in Japanese political education noted by Kodama, such as "subject matter presented in a passive, uncritical matter...and lack of an encouraged critical perspective for students," there are powerful resources in Japan's civic life and cultural history to push back against the dominant view and promote a paradigm of democracy as society. ${ }^{5}$ My presentation has three elements:

1) The international context.

2) Signs of an emergent paradigm of democracy-as-society.

3) Emerging resources in Japanese civic culture for this new paradigm and for global leadership in advancing it.

I conclude with a call for international conversation and collaboration on this paradigm.

\section{1) The international context: Civic unraveling}

In his Mandela Day Lecture in South Africa, on July 17, 2018, former US president Barack Obama conveyed both hope and a sober message. "I believe in Nelson Mandela's vision of equality and justice and freedom and multi-racial democracy, built on the premise that all people are created equal and they're endowed by our creator with certainly inalienable rights," he said. He noted that people around the world are claiming their distinctive stories and advancing egalitarian claims and values. Yet subjective identities are easily manipulated:

- "A politics of fear and resentment and retrenchment...is now on the move... at a pace that would have seemed unimaginable just a few years ago... 
- Strongman politics are ascendant suddenly [and] those in power seek to undermine every institution or norm that gives democracy meaning."

- Even developments which were once seen as positive create dangers. "Social media -once seen as a mechanism to promote knowledge and understanding and solidarity -has proved to be just as effective promoting hatred and paranoia and propaganda and conspiracy theories." 6

Deep underlying dynamics feed such dangers:

In the United States today and elsewhere partisan and cultural differences are inflamed by technologies of mobilization which devalue and demonize opponents. The left as well as the right contribute to this dynamic. Parents worry more that their children will marry someone of a different political party than that their children will marry someone of a different race. $^{7}$

The dynamics of technocracy and consumerism create niche identities. Indeed, formal politics is significantly based on these. Hillary Clinton's two campaigns, in 2008 and again in 2016, were based on conceiving of the electorate as consumer niches. In December 2007, during the 2008 campaign, her chief strategist Mark Penn, long a master in campaigning as "niche marketing," designed an advertisement in which Clinton was dressed up as Santa Claus, passing out benefits to various groups.

Finally, social and civic fragmentation, eroding social capital, are growing and the digital revolution feeds this process. Dhruv Khullar, a resident physician at Massachusetts General Hospital and a faculty member of Harvard Medical School, reports that since the 1980s the number of adults who identify as lonely has skyrocketed as social relationships and social networks have shrunk. ${ }^{8}$ Research finds that young people under 35 , high social media users, feel most alone. ${ }^{9}$

These dynamics produce a culture of fear. Parents are legally in jeopardy in 19 states for letting their children go unattended. Kim Brooks described the results in the New York Times. In her home town growing up in the 1980s, she "had spent hours waiting in the back seat of my parents' station wagon, windows open, reading or daydreaming while they ran errands." But when she left her four year old alone in her car for a few minutes in the same town while she did an errand, a stranger called the police. When she got a message on her phone from the authorities, she knew what had happened. "And so I waited, terrified, until the morning I received a second call and learned that I was being charged with contributing to the delinquency of a minor - my son." She adds, "So now children do not walk to school or play in the park on their own. They do not wait in cars. They do not take long walks through the woods..."

In the US there has been a striking loss of the culture of the productive citizenship and mutual responsibility and connection across differences which animated earlier periods of democratic change like the New Deal and the civil rights movement.

\section{2) Signs of the emerging alternative}

Echoing theorists such as Emmanuel Levinas, who notes that the struggle to affirm oneself "without regard for the Other" can result in savagery and violence, Obama observes, "People elevate themselves by putting somebody else down." In his address, Obama proposed 
a "respectful amendment" to Mandela's emphasis on struggle against injustice. "It's not enough for us to protest; we're going to have to build." Obama is pointing to a new paradigm of citizen-centered democracy. Here is a chart on how it compares with state centered liberal and communitarian paradigms.

\begin{tabular}{|l|l|l|l|}
\hline $\begin{array}{l}\text { Frameworks of civic } \\
\text { education }\end{array}$ & Liberal & Communitarian & Public work \\
\hline What is democracy? & Free elections & Civil society & Way of life \\
\hline What is the citizen? & Voter & Volunteer & Co-creator, civic producer \\
\hline What is citizenship? & Voting & Service & Public work \\
\hline What is politics? & $\begin{array}{l}\text { Struggle over scarce } \\
\text { resources - Who gets } \\
\text { what? }\end{array}$ & Search for unity & $\begin{array}{l}\text { Engagement across differences to create a } \\
\text { common life }\end{array}$ \\
\hline What is power? & Power over Zero sum & Power with & Power to Generative, expansive \\
\hline $\begin{array}{l}\text { What is the aim of } \\
\text { education? }\end{array}$ & $\begin{array}{l}\text { Knowledge and } \\
\text { technical skills }\end{array}$ & Moral education & $\begin{array}{l}\text { Developing civic agency, new habits of mind } \\
\text { and action }\end{array}$ \\
\hline $\begin{array}{l}\text { How is success } \\
\text { measured? }\end{array}$ & \begin{tabular}{l} 
Tests \\
\hline
\end{tabular} & $\begin{array}{l}\text { Demonstrating good } \\
\text { character }\end{array}$ & $\begin{array}{l}\text { Signs (including self-assessment) of growth in } \\
\text { civic agency habits and political awareness }\end{array}$ \\
\hline
\end{tabular}

Despite the civic and social unraveling, signs of the new paradigm in which citizens are at the center are appearing. Obama's new foundation has this emphasis. As he put it at the launch of the foundation in Chicago on October 30, 2017, "What's wrong with our politics is a reflection of something that's wrong with the civic culture, not just in the United States but around the world." 11 The website of the foundation describes its efforts as an "experiment in citizenship." Its mission is "to inspire and empower people to change their world."

In the US, multiplying real world movements also have this approach. A new effort called Better Angels, co-founded by our long-time colleague in public work William Doherty, aims to depolarize America. In June, delegates from across the country adopted a declaration explicitly challenging the "take-over" of politics by those who seek polarization. "Our nation is in trouble. The crisis we face is polarization," it reads. "What endangers us is not the rise or decline of either party, but our loss of trust in each other and the take-over of our politics by those in both parties who would have us put faction over country, treat our opponents as enemies, and reject the idea of common ground."13 Better Angels is part of a wave of citizen reform movements which cross partisan divides, in which the language of We the People is returning, many described in the documentary by Pulitzer-Prize winning journalist Hedrick Smith, "The Democracy Rebellion." Smith, long the leading reporter for the New York Times on the Cold War, argues "today the grassroots are riled up and rising up." "I've long had the idea that I'm continuing the American Revolution," said Linda Block, who collected 21,000 signatures in 2016 to get initiative 735 on the Washington state ballot. The Initiative, passed in the fall of 2016, aims to end unlimited corporate contributions to elections. She told Smith, "Every signature I get I see as a check for the power of "We the People." The documentary details efforts to end corporate money in campaigns, restrict illegal rigging of congressional boundaries, disclose "dark money" or secret campaign contributions, thwart efforts to repress voting, pass public financing for campaigns and address other political dysfunctions. "We are seeing activism that we haven't seen in years," observed Karen Flynn, who helped lead the fight for public financing of campaigns in Connecticut. "People are hungry 
for reform and concrete actions they can take." 14

Signs of a new paradigm in which citizens are central can be seen around the world. The Theology of the People movement in Argentina, which shaped Pope Francis, puts citizens at the center of making change. The Public Achievement youth civic education and empowerment initiative and other public work movements, based on public work, citizen politics, and free spaces, are part of these efforts at civic repair. ${ }^{15}$

Theoretical developments also undergird this shift. Public Achievement and its theory, public work, are wellsprings of the new transdisciplinary field of Civic Studies, also called a "new civic politics." The field, disseminating resources for civic life and citizen action, poses the question "what should we do as citizens?" I helped to found Civic Studies in 2007 as one of seven engaged political theorists, including the late Elinor Ostrom, winner of the Nobel Prize for Economics for her work in citizen governance of common pool resources. We launched Civic Studies in part to challenge the assumption that academics are outside observers and analysts and professionals and those in government are fixers and service providers, not fellow citizens. Civic Studies stresses political agency and citizens as co-creators of communities at different scales. Ostrom entitled her Lecture "Beyond Markets and States." 16

A theory of democracy as a way of life, politics as pluralistic, not partisan, and citizens as co-creators draws from culturally grounded views of citizenship antecedent to the modern state, as Isak Tranvik, a political theorist studying at Duke University, has emphasized. ${ }^{17}$ Tranvik shows how the thought of Vaclav Havel, a leader of the Czech freedom movement, is in this vein. Havel drew on Czech traditions of "honest and responsible work in widely different areas of life" which contribute to society: "Havel does not think the state can usher in a more just political order." Havel said, "Life is something unfathomable, ever-changing, mysterious, and every attempt to confine it within an artificial, abstract structure inevitably ends up homogenizing, regimenting, standardizing and destroying life." 18

Finally, the paradigm of democratic society has a rich but submerged pedagogical genealogy in approaches to education which aim at development of human agency and human flourishing, antecedent to the rise of modern states. It is no accident that Public Achievement, begun in 1990 as a way for young people to experience the empowering, democratic, nonideological politics which I encountered in the citizenship schools of the civil rights movement, has been picked up by colleagues at Tokai University. Both Tokai University and the citizenship schools draw on premodern understandings of the citizen, in particular N.F.S. Grundtvig's philosophy of Danish Folk Schools. The Danish folk schools had a focus on "education for life" including the public and society-building dimensions of every kind of work. Marie-Louise Ström, for many years director of popular education at the Institute for Democracy in South Africa, led a team which integrated Scandinavian Danish folk school pedagogies and public work across Africa, finding ancient roots of such themes in many cultures. On 3 September, 2018, at a symposium at the University of Tokyo, I argued that professional work which occasions and sustains free spaces where people have a free intellectual life with diverse voices and find opportunities to develop political agency is citizen professional work, a next frontier of democracy.

In response to academic arguments that most people are in the grip of raw instincts, John Dewey, who studied in Japan in 1919, theorized on Jane Addams' Hull House settlement for new immigrants. Hull House created an example of a free space, with an educational culture like that of the folk schools, full of interactions among different ethnic groups, 
appreciation for diverse work traditions, and political plurality. ${ }^{19}$ Dewey observed that "habits," not "instincts," shaped such democratic cultures. Habits, in his description, are not blind repetitions but learned patterns which create predispositions for action in unexpected circumstances. They can be consciously changed and developed, an idea which proved fertile for democratic educational innovation. Thus Deborah Meier, a K-12 democracy educator in the United States, founded highly successful public schools in East Harlem, New York and Boston based on cultivating democratic habits. Three habits of mind and action are particularly important in developing political agency:

- Thinking politically, not simply normatively in terms of what "should be." How do young people learn to see the diverse interests, power dynamics, stories, injustices and resources of any environment, "the world as it is"?

- Thinking relationally, "we," not simply "me." How do young people learn to build working relationships across sharp differences and learn to see and sustain free spaces where such relationships are built?

- Thinking as a producer, not simply as a consumer. How do young people see themselves as responsible co-creators of a common life and the commonwealth, not only as claimants of rights and recipients of goods and services?

There are resources in Japanese culture for this paradigm of democratic society.

\section{3) Resources in Japanese civic life and culture for a new paradigm}

Walter Enloe, who spent his youth in Hiroshima and later was principal for eight years of the Hiroshima International School, described how Japanese culture develops strong civic habits and self-organizing practices in everyday life. Neighbors clean communities and help each other. Children organize to clean schools, serve meals, and mentor younger children. In response to the article by Kim Brooks, "Motherhood in the Age of Fear," many wrote the New York Times about the greater freedom of Japanese children. "At 8 my son walked to a store alone for the first time," said one parent now living in Bronxville, New York. "He got his Pokemon cards even though he didn't speak Japanese and the proprietor didn't speak English." Another, now in Los Angeles, wrote that "all over Japan, it Is common to send youngsters on complicated errands such as going alone into town to buy fish for dinner and come back with the correct change." Another colleague, Professor Matt Filner, who had a Fulbright Fellowship at the University of Tokyo in the Political Science department, described his surprise at children negotiating public transport by themselves. A writer to the Times, now in Los Angeles, wrote, "In Tokyo, it is common to see the young children (even first and second graders) taking all sorts of public transportation, cross pedestrian bridges over train stations, meet their schoolmates on the train platform to ride to school. Zero adult supervision." ${ }^{20}$ Such patterns involve civic trust as well as civic habits.

In his study of community life in Japan, part of a global research study called "The Decline of Social Capital," Professor Takashi Inoguchi reports on cultural and civic traits that have made "social capital" resilient in Japan through the 1990s, unlike other countries in the study. He writes, "Civic activities in the neighborhood and community do not seem to have been negatively affected by the onslaught of urbanization, industrialization, and market liberalization over the past 50 years." In fact, civic activities involving children, the aged, and the 
disadvantaged rose rapidly. ${ }^{21}$ In response to the Great Hanshin-Awaji Earthquake on 17 January, 1995, enormous numbers of volunteers came to help, "all the more remarkable because of the contrast with the generally inept and slow action taken by the central government." 22 Egalitarianism and anti-authoritarianism are strong compared to the United States or the United Kingdom, with little evidence of a "deferential political culture." In fact, evidence suggests a shift away from trust in politicians toward trust in everyday citizens. In 1953, 43 percent of the population agreed with the proposition that "it is better to choose the good politicians... and entrust them to resolve problems rather than for the people to debate the issues." By 1993, that percentage had dropped to 25 percent. ${ }^{23}$ These patterns have old roots. The Catalogue of the Edo-Tokyo Museum describes cooperative traditions of the townspeople centuries old. "Although they lived in a cramped environment... residents learned to help each other. The world of 'Kuma-san, Hattsan'...emerged from such daily lives.",

While Inoguchi notes long-term trends in political culture, such as a decentralized political system, which undergird strong civic life, these patterns did not generate a plural politics. Instead, his study indicates that Japanese culture generated what is called "bonding" social capital, cultivating obligation "only toward a narrow range of 'socially known' others." Trust of others outside the range is low. Eiko Ikegami calls this pattern "honorific collectivism," tracing its roots to the periods from Tokugawa to Showa, extending from about 1600 to 1989. ${ }^{25}$ According to Inoguchi, the dominant political culture "was the decentralized-quasi-feudal, highly bureaucratic Tokugawa regime." The modern Japanese state "extended and expanded this spirit into a version of nationalistic and collectivist spirit," which fed the imperial government of the first half of the twentieth century. ${ }^{26}$

In the twenty-first century, Inoguchi sees a new stage emerging based on a shift from honorific collectivism and bonding social capital to more open interaction and relationships among strangers. "Japan is in transition from relatively closed to relatively open social capital," "cooperative individualism," he writes. ${ }^{27}$ Social capital theorists call such interaction among strangers "bridging social capital," but a better description is pluralist, productive citizen politics.

Citizen-centered politics has old roots in Japanese settings which taught habits of work and interaction across differences. Thus in Edo in the eighteenth and nineteenth century,

"People and information from all over the country gathered [and] there was an ambiance of freedom unique to cities, where people could find friendship regardless of social class. Daimyō, Samurai of different domains, townspeople [of] various occupations, and literati from the provinces gathered as fellows that shared common interests and scholarship...cultural salons as such were formed in Edo, one after the other, and played a significant role in the making of Edo Culture. Diverse culture emerged through such liberal interactions. $" 28$

In the early twentieth century Christianity, emerging from the underground, generated democratic experiments in pluralist citizen politics and pedagogy. For instance, Kanzō Uchimura, a "non-church" Christian and agriculture professor, became a strong advocate for Danish folk schools and the philosophy of N.F.S. Grundtvig. He was impressed with the ways in which nineteenth century Denmark, adopting Grundtvig's philosophy of "education for life" on a large scale, based on human flourishing and development of the capacities of ordinary people, was able to experience a broad social and economic revitalization. In Representative Men of Japan, written during the war with China, Uchimura also highlighted a philosophical 
and political tradition he saw as an alternative to the bellicose nationalism of bushido. ${ }^{29}$

Uchimura's followers included a young engineer, Shigeyoshi Matsumae, who participated in his study group, an intellectual community aimed at practical application which brought together scientists, humanists, and others concerned with democratic change. The experience shaped Matsumae's life. As he put it in My Turbulent Life in a Turbulent Century, he "came to the conclusion that the most vitally important and necessary factor [for societies] was...a broad, humanistic education founded on history, philosophy and ideas, by means of which a tolerant and humanistic view of life and the world could be cultivated in our young people." His life goal became creating "a university where young people would be free to exercise their creativity... and where science and technology could be harnessed to the furtherance of the peace and happiness of mankind."

Subsequently Matsumae became one of the world's leading engineers, inventing the non-loaded cable, the foundation of global telecommunications. His dissertation committee protested his preface, which argued that "science and technology should not be the slaves of a materialist civilization nor the tools of the egoism of scientists and technologists, but should contribute to the peace and happiness" of humanity, but backed down when he threatened to withdraw the thesis. His autobiography recounts many such instances of a fierce spirit which led him to challenge arbitrary authority.

In his autobiography Matsumae wrote with prophetic insight about the dangers of technocratic domination in the emerging world. "Information processing and machine handling capabilities" were accelerating. "On the other hand," he said, "I have a feeling that what is being ignored...is education of man as a living human being...part of the totality of creation." He saw "an imbalance between intellectual development on the one hand and spiritual and physical development on the other." 30

To actualize his philosophy of full education of the "living human being," Matsumae founded Tokai University after World War II. Tokai has become a leading STEM university. It is adopting what educators call "Public Achievement-style education" across all its regional campuses. When Marie Ström and I visited Tokai in 2018, Mayuko Horimoto and Sachi Ninomiya-Lim, leading the process, were frank about the challenges of large-scale faculty development for a pedagogical paradigm shift from the passive instructional approach, which Kodama identified as an obstacle to active political education. Despite the challenges, we were both impressed by the effort and its scale, seeking to spread a different paradigm on a large scale and to create a different learning culture. After several years of pilot projects, they were expanding Public Achievement-style education to bring the philosophy of citizens as co-creators and active learning pedagogy to 7,000 entering freshmen on eight regional campuses. Eventually all 30,000 nonmedical school students will take a "Concept of Citizenship" course, another called "Understanding Local Communities," a course on "Concept of Voluntarism," and a course on "Understanding Global Communities." This year they are able to take follow-up courses such as "Public Work," "Public Skills, and "Coaching Practice." Public Achievement-style education is a significant experiment in teaching a different framework of democracy centered on citizens.

In 1939, John Dewey issued a challenge to those who believe that democracy rests on formal institutions. Beware, he said, of the "belief that [totalitarian] states rest only upon unmitigated coercion and intimidation." As Melvin Rogers recently put it, "For Dewey, democracy's survival depends on a set of habits and dispositions - in short, a culture - to sustain 
it. [Institutional] checks and balances do not have an agency of their own. A democracy is only as strong as the men and women who inhabit it." 31

For the sake of democracy's future, we need strong citizens who can talk and think well about what it means to be a citizen in a democracy with the skills and habits of putting strong citizenship into practice. This requires a refocusing on democratic culture and identification of "schools for democracy" where people develop such capacities.

The future depends on international collaboration and conversation about such politics, citizenship, and democracy.

\section{Notes}

1 Murray Print, Shigeo Kodama, Wangbei Ye, Sugianto Tandra, "Political Education in Asian Schools," Lange, D \& Reinhardt, V (eds) Basiswissen Politische Bildung (Basic Knowledge of Political Education) (Baltmannsweiler, Germany: Schneider-Verlag Hohengehren, 2017), pp 406420.

2 Quoted in Denise Egea-Kuehne, “'Subjectification': Biesta's Strong Link to Education," Philosophy of Education (2009), p. 363.

3 Gert Biesta, "The Ignorant Citizen: Mouffe, Ranciere, and the Subject of Democratic Education," Studies in Philosophy and Education Vol. 30, No. 2 (2011), p. 152.

4 Jonna Pettersson, "Rethinking political subjectification: Equality beyond a community of sameness," Distinktion: Scandinavian Journal of Social Theory Vol. 1, no. 3 (2011), p. 264.

5 See Sara M. Evans and Harry C. Boyte, Free Sources: The Sources of Democratic Change in America Second edition (Chicago: University of Chicago, 1992).

6 Barack Obama, "Mandela Day Lecture," July 17, 2018, Johannesburg, South Africa, https://www. nelsonmandela.org/content/page/annual-lecture-2018

7 See the extensive survey data on "Better Angels," https://www.better-angels.org/

8 Dhruv Khullar, "How Social Isolation Is Killing Us," New York Times December 22, 2016.

9 Natalie Gil, "Loneliness: A Silent Plague That Is Hurting Young People the Most," Guardian, July 20, 2014. The Mental Health Foundation found "Loneliness [is] a greater concern among young people than the elderly. The 18 to 34-year-olds surveyed [are] more likely to feel lonely often, to worry about feeling alone and to feel depressed because of loneliness than the over55s."

10 Kim Brooks, "Motherhood in the Age of Fear," New York Times, July 28, 2018.

11 Personal notes, October 30, 2017.

12 "About the Foundation," Obama Foundation, www.obama.org/about-the-foundation/.

13 "An American Declaration," Better Angels website, https://www.better-angels.org/

14 Hedrick Smith, "Democracy Rebellion," American Public Television 2020.

15 See Harry C. Boyte, Awakening Democracy through Public Work (Nashville: Vanderbilt University Press, 2018).

16 https:/en.wikipedia.org/wiki/Civic_studies; Peter Levine, "The Case for Civic Studies," in Levine and Soltan, Civic Studies, 7; https://www.nobelprize.org/prizes/economic-sciences/2009/ostrom/lecture/.

17 In his unpublished essay, "Public Work as Vocation," Tranvik reflects on his visit to Wittenberg, Germany, where he "was surprised to find a rich concept of 'citizenship' amidst the edicts and papal bulls that filled Martin Luther's old house." In Tranvik's view, writing before modern revolutions "meant that Luther was forced to think hard about what it meant to live a public life without worrying how voters could collective create a common good that elected representatives translate into action...to conceptualize politics beyond government and citizenship without voting." Luther, in Tranvik's opinion, developed a "social ontology" of public life, rather than an individualist one.

18 Isak Tranvik, "Chapter Two - An Existential Revolution," from dissertation in political theory at Duke University, forthcoming. 
19 Jane Addams, in fact, had a far more pluralist understanding of politics describe than did Dewey, as described in Harry C. Boyte, "John Dewey and Citizen Politics: How Democracy Can Survive Artificial Intelligence and the "Gospel of Efficiency," 2017 John Dewey Society lecture, Education and Culture Vol. 33, No. 6 (2017), pp. 10-44.

20 The New York Times published comments about Japan and other countries a month ago, edited by Lela Moore, "From Tokyo to Paris Parents Tell Americans to Chill," August 2, 2018.

21 Takashi Inoguchi, "Social Capital in Japan," Japanese Journal of Political Science Vol. 1, No. 1 (2000), p. 78 .

22 Ibid., p. 102.

23 Ibid., pp 93-94; 79-81.

24 Edo-Tokyo Museum, Permanent Exhibition Catalogue (Tokyo: Ed-Museum, 2018), p. 24

25 Inoguchi, "Social Capital," pp. 104-105.

26 Ibid., pp. 99-100

27 Ibid., pp. 101, 104-105.

28 Edo-Kokyo Museum Catalogue, p. 50.

29 https://www.amazon.com/Representative-Men-Japan-English-Japanese/dp/4770029284

30 Shigeyoshi Matsumae, My Turbulent Life in a Turbulent Century (Tokyo: Tokai University Press, 1982), pp. 41 pp 41, 14, 117, 208-209.

31 Melvin Rogers, "Democracy Is a Habit," Boston Review, July 28, 2018. 